\title{
PEMBERDAYAAN WIRAUSAHA MELALUI DIGITAL MARKETING MASYARAKAT DESA MENANG RAYA KECAMATAN PEDAMARAN KABUPATEN OGAN KOMERING ILIR SUMATERA SELATAN
}

\author{
Adi Inggit Handoko, Rindang Senja Andarini, Oemar Madri Bafadhal \\ Universitas Sriwijaya \\ E-mail : adiinggit@ fisip.unsri.ac.id
}

\begin{abstract}
Abstrak
Desa adalah sebuah perwujudan geografis (wilayah) yang ditimbulkan oleh unsur-unsur geografis sosial, ekonomi, politik, dan kultural dalam hubungan dan pengaruh timbal baliknya dengan daerah- daerah lain disekitarnya. Sebagai wujud pengakuan Negara terhadap Desa, khususnya dalam rangka memperjelas fungsi dan kewenangan desa, serta memperkuat kedudukan desa dan masyarakat desa sebagai subyek pembangunan, diperlukan kebijakan penataan dan pengaturan mengenai desa yang diwujudkan dengan lahirnya UU Nomor 6 Tahun 2014 Tentang Desa. Pedamaran memiliki beberapa sumber daya alam yang dapat dimanfaatkan warga. Disana terdapat lebak lebung atau danau yang dapat dimanfaatkan warga untuk mencari ikan, mengambil tanaman purun untuk dimanfaatkan sebagai berbagai macam kerajinan tangan dan menggembalakan kerbau rawa. Hasil dari kegiatan ini adalah melalui program kerja utama, masyarakat Desa Menang Raya sadar akan besarnya andil pemasaran online (digital marketing) dalam memasarkan produk unggulan desa berupa kerajinan purun dan kemplang. Kesadaran ini didukung dengan pelatihan pembuatan akun e-commerce dan juga pengambilan foto produk agar menarik perhatian pembeli, sehingga masyarakat khususnya pengrajin purun dan pembuat kemplang siap untuk merintis bisnis online-nya.
\end{abstract}

\section{Kata Kunci: KKN, Pedamaran, Purun, e-Commerce}

\section{Pendahuluan}

Desa adalah sebuah perwujudan geografis (wilayah) yang ditimbulkan oleh unsur-unsur geografis sosial, ekonomi, politik, dan kultural dalam hubungan dan pengaruh timbal baliknya dengan daerah-daerah lain disekitarnya. Dikutip dari Encyclopaedia Britannica (2015), desa adalah komunitas yang tidak terlalu padat penduduk, dengan kegiatan ekonomi utama berupa produksi pangan dan bahan-bahan mentah. Adapun berdasarkan Undang-Undang No.6 tahun 2014 tentang Desa, desa adalah kesatuan masyarakat hukum yang memiliki batas wialayah yang berwenang untuk mengatur dan mengurus urusan pemerintahan, kepentingan masyarakat setempat berdasarkan prakarsa masyarakat, hak asal usul, dan / atau hak tradisional yang diakui dan dihormati dalam sistem pemerintahan.

Sebagai wujud pengakuan Negara terhadap Desa, khususnya dalam rangka memperjelas fungsi dan kewenangan desa, serta memperkuat kedudukan desa dan masyarakat desa sebagai subyek pembangunan, diperlukan kebijakan penataan dan pengaturan mengenai desa yang diwujudkan dengan lahirnya UU Nomor 6 Tahun 2014 Tentang Desa.

Dalam perspektif baru, desa sekarang tidak bisa dikategorikan dengan desa pada zaman dahulu, yang dianggap bahwa masyarakatnya kecenderungan masyarakat dengan mata pencaharian bercocok tanam, tinggal dengan keadaan yang seadanya. Pada saat ini desa dituntut untuk mandiri, sejak pemerintah memiliki program untuk pembinaan desa melalui Program Dana Desa maka desa pada saat ini berbenah dengan mengembangkan potensi yang dimiliki oleh desa. Dalam informasi resmi djpk.kemenkeu.co.id bahwa penggunaan Dana Desa diprioritaskan untuk membiayai pembangunan dan pemberdayaan masyarakat yang ditujukan untuk meningkatkan kesejahteraan 
Jurnal SEMAR Vol. 10 No. 1 , hal. $78-84$

ISSN: 2302-3937 | Copyright @ LPPM Universitas Sebelas Maret Homepage: https://jurnal.uns.ac.id/jurnal-semar

masyarakat desa, peningkatan kualitas hidup manusia serta penanggulangan kemiskinan dan dituangkan dalam Rencana Kerja Pemerintah Desa.

Dikutip dari Profil Desa Pedamaran, wilayah Pedamaran memiliki beberapa sumber daya alam yang dapat dimanfaatkan warga. Disana terdapat lebak lebung atau danau yang dapat dimanfaatkan warga untuk mencari ikan, mengambil tanaman purun untuk dimanfaatkan sebagai berbagai macam kerajinan tangan dan menggembalakan kerbau rawa. Terdapat juga kebun sawit dan kebun karet milik warga yang dapat membantu perekonomian warga. Selain perkebunan karet dan perkebunan sawit, masyarakat Pedamaran membuat kerajinan tikar yang berasal dari purun. Cara pembuatan tikar purun masyarakat Pedamaran dilakukan secara tradisional. Penjualan tikar purun pun masih dilakukan secara manual, dijual dengan cara dipasarkan dipasar tradisional dan dibawa ke pasar yang ada dikota sekitaran Sumatera Selatan, bahkan dibawa ke Lampung. Selain potensi kerajinan tangan, Pedamaran juga memiliki potensi ikan air tawar, ikan air tawar yang selama ini diperoleh dengan budidaya ikan melalui keramba. Pengelolaan sumber alam ikan air tawar ini dimanfaatkan oleh masyarakatnya untuk membuat kerupuk, ikan salai (ikan yang dipanggang sampai kering), pempek, dan biasanya masyarakat pedamaran menjual ikan tanpa diolah sebelumnya. Selain dijual, ikan yang diperoleh selama ini hanya dimanfaatkan untuk dikonsumsi sendiri.

Potensi desa ini menarik untuk dikembangkan, ditengah penggunaan teknologi yang berkembang saat ini dan tengah berkembangnya pemasaran melalui e-commerce seharusnya masyarakat pedamaran mulai menyadari bahwa potensi yang dimiliki ini perlu dipasarkan secara luas, bukan hanya terbatas hanya dikalangan warga desanya saja. Dengan menggunakan kemampuan teknologi ini diharapkan produk lokal desa Menang Raya Pedamaran ini dikenal secara luas oleh masyarakat nasional maupun internasional. Potensinya wilayahnya ada, masyarakat yang terus mengembangkan potensi ini juga ada. Masalahnya adalah bagaimana tingkat pemahaman masyarakat untuk menyadari potensi ini hingga dikembangkan menjadi pendapatan asli desa di wilayah Desa Menang Raya Pedamaran. Tantangan yang perlu dipecahkan adalah bagaimana masyarakat mampu memanfaatkan teknologi sebagai media pemasaran. Karena jika dilihat potensi sumber daya manusianya, masyarakat Desa Menang Raya Pedamaran cenderung belum melek teknologi secara penuh, maksudnya bahwa penggunaan teknologi ini hanya dimanfaatkan untuk kebutuhan media sosial yang tidak memiliki dampak bagi warga masyarakat.

Kuliah Kerja Nyata (KKN) Tematik ini adalah sebagai upaya yang dilakukan antara sinergi akademis dengan masyarakat untuk memecahkan persoalan yang dimiliki oleh masyarakat Desa Menang Raya Kecamatan Pedamaran Kab. OKI Sumatera Selatan setidaknya dengan adanya kegiatan KKN Tematik ini diharapkan mampu untuk menstimulus masyarakat agar lebih mau untuk mengembangkan potensi di desanya. Selain itu juga, kegiatan KKN merupakan wujud nyata dan implementasi tri darma perguruan tinggi.

\section{Metode Pelaksanaan}

Bentuk kegiatan terdiri dari kegiatan utama dan kegiatan pendukung. Kegiatan utama dalam KKN ini adalah program kewirausahaan dilakukan dalam bentuk kegiatan workshop dengan melibatkan penggiat UMKM di Desa Menang Raya Kecamatan Pedamaran. Untuk kegiatan pendukung, pelaksanaannya dilakukan dalam bentuk partisipasi mahasiswa yang dikemas dalam pendampingan partisipatif.

\section{Hasil dan Pembahasan \\ C. 1 Pelatihan Promosi Digital Secara Online dengan Memanfaatkan Teknologi}

Pelatihan Promosi Digital Secara Online dengan Memanfaatkan Teknologi di lakukan selama tiga hari. Hari pertama dihadiri oleh para pengrajin purun dan pembuat kemplang dari Dusun III, Desa Menang Raya. Konsep acara yang diangkat pada kegiatan ini bersifat informal dengan harapan dapat membuat peserta lebih nyaman untuk berkomunikasi sehingga dapat terlaksana komunikasi dua arah antara pemateri dan peserta.

Kegiatan ini diawali dengan pembukaan untuk menyampaikan tujuan dan jalannya kegiatan ke peserta yang kemudian dilanjutkan dengan penyampaian materi seputar "Digital Marketing" oleh narasumber. Pada sesi ini disampaikan bahwa salah satu permasalahan wiraswasta di Pedamaran adalah cara penjualan produk kerajinan Purun, terutama tikar Purun. Apabila produk ini hanya 
Jurnal SEMAR Vol. 10 No. 1 , hal. $78-84$

ISSN: 2302-3937 | Copyright @ LPPM Universitas Sebelas Maret Homepage: https://jurnal.uns.ac.id/jurnal-semar

dipasarkan di Pedamaran saja maka dinilai kurang efektif karena di daerah ini hampir semua orang bisa menganyam tikar Purun. Oleh karena itu, para peserta diberi kesadaran akan pentingnya pemasaran keluar Pedamaran, terutama pemasaran dengan menggunakan teknologi digital di era modern ini.

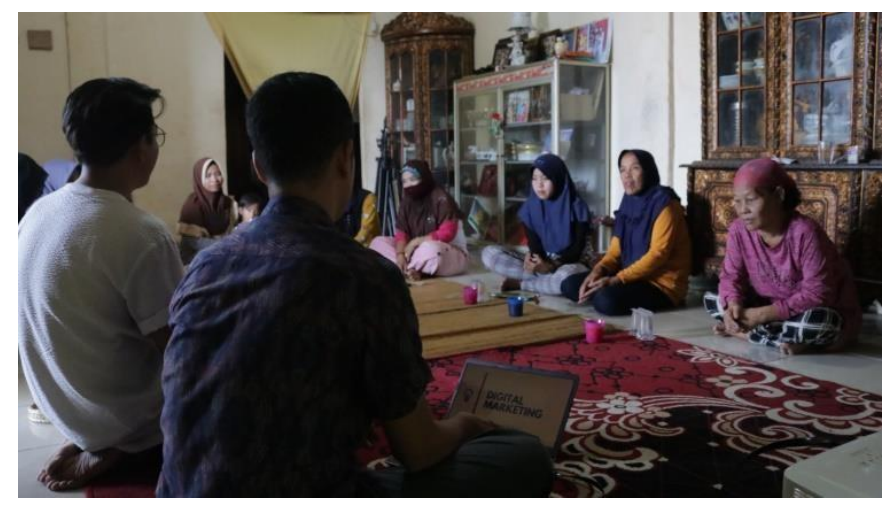

Gambar 1. Pemateri sedang melakukan sesi sharing dengan pengrajin Purun

Perihal alasan menggunakan sistem pemasaran online dalam penjualan produk unggulan desa ini juga disampaikan kepada para peserta. Di mana melalui sistem ini cakupan konsumen lebih luas hingga dapat menyentuh konsumen yang berada di luar pulau bahkan di luar negeri. Selain itu melalui pemasaran online, selera konsumen juga dapat dipengaruhi. Masyarakat kota di era modern ini sangat rentan terpengaruh untuk mengikuti tren yang sedang berlangsung, sehingga apabila suatu produk dinilai unik dan menarik oleh beberapa orang, terlebih public figure yang terkenal, maka produk tersebut dapat menjadi high demand akibat pengaruh dari tren. Oleh karenanya apabila terdapat produk kerajinan purun yang unik dan menarik, kemungkinan produk tersebut untuk diminati apabila dipasarkan secara online menjadi lebih tinggi.

Ketika membicarakan pemasaran online, maka tidak terlepas dari $e$-commerce yang bermunculan di Indonesia. Penggunaan e-commmerce dalam pemasaran online dinilai lebih menguntungkan, baik dari segi penjual maupun pembeli. Melalui transaksi jual beli menggunakan e-commerce seperti Shopee, Tokopedia, Bukalapak, dan sebagainya, segala bentuk penipuan dalam transaksi jual beli dapat diminimalisir, terdapat efisiensi waktu, serta tidak memerlukan etalase fisik.

Setelah mengetahui pentingnya dan keunggulan menggunakan sistem pemasaran online dalam menjual produk unggulan desa yang dimiliki, para peserta diajak untuk langsung membuka akun penjual dan mengunggah salah satu produk unggulan desa yang ada pada e-commmerce Shopee. Shopee dipilih sebagai e-commerce yang digunakan dalam pelatihan ini karena ia merupakan e-commerce yang memiliki jumlah pengguna terbanyak saat ini sehingga peluang berjualan online di Shopee lebih besar. Selain itu pemasaran produk di Shopee terbilang tidak sulit sehingga mudah diingat dan dilakukan.
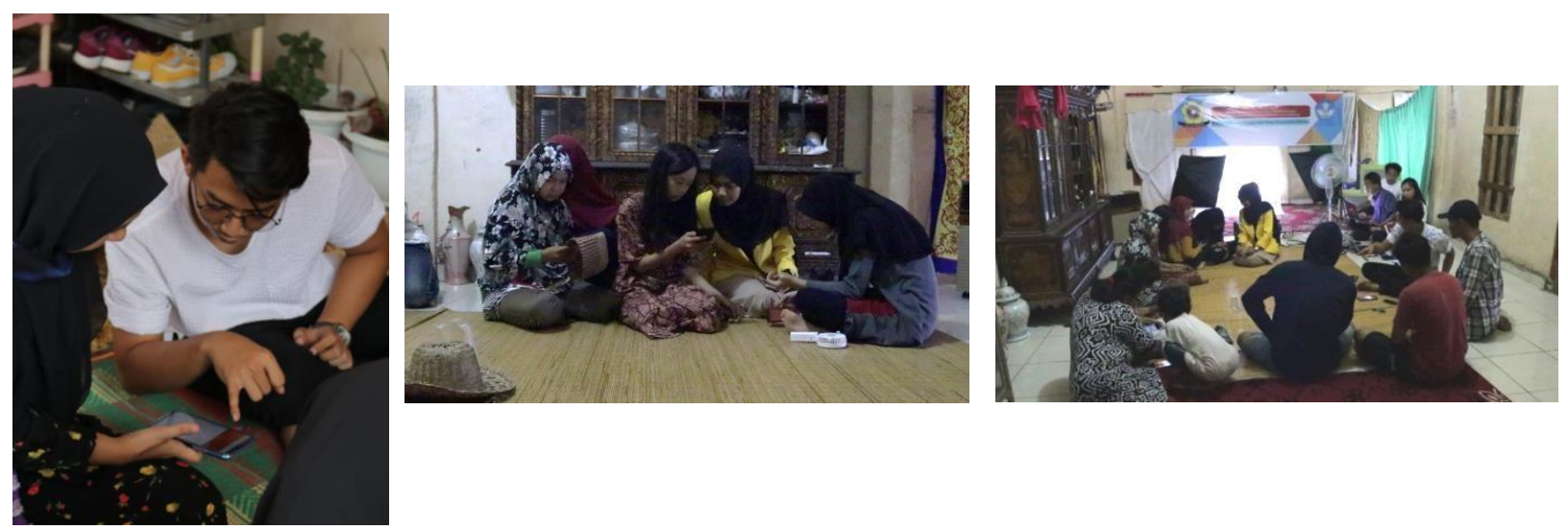

Gambar 2. Pendampingan peserta dalam menggunakan aplikasi Shopee di hari pertama pelatihan promosi digital 
Jurnal SEMAR Vol. 10 No. 1 , hal. $78-84$

ISSN: 2302-3937 | Copyright @ LPPM Universitas Sebelas Maret Homepage: https://jurnal.uns.ac.id/jurnal-semar

Pertama-tama para peserta diajak untuk menginstall aplikasi Shopee di smartphone masingmasing peserta terlebih dahulu. Bagi peserta yang tidak memiliki smartphone dapat ikut belajar bersama peserta lain, dan kelak apabila ingin ikut berjualan online dapat menggunakan akun penjual milik peserta lain. Dalam proses install aplikasi ini, terdapat kendala di mana beberapa smartphone peserta kehabisan memori penyimpanan sehingga perlu waktu yang cukup lama untuk menyortir dan mengosongkan memori dan mengunduh aplikasi Shopee tersebut.

Ketika semua peserta telah siap dengan aplikasi Shopee-nya, para peserta diberi arahan untuk membuat akun penjual Shopee melalui langkah-langkah yang ditampilkan dalam bentuk PowerPoint dan didampingi oleh Tim KKN Tematik UNSRI. Adapun pembuatan akun penjual Shopee hanya perlu mendaftar melalui nomor telepon, menunggu kode verifikasi yang didapat dari SMS, dan kemudian mengatur password. Setelah seluruh peserta memiliki akun penjual Shopee, mereka diarahakan untuk mulai mengunggah salah satu produk kerajinan purun sebagai contoh cara berjualan produk di aplikasi Shopee. Cara memulai untuk menjual produk adalah dengan mengklik "SAYA" yang berada di kanan bawah beranda, lalu klik "MULAI JUAL" yang ada di kiri atas halaman, kemudian mengklik "TAMBAH PRODUK". Setelahnya penjual perlu menunggah foto produk, mengisi Nama Produk, Deskripsi Produk, Kategori, Harga, Stok, Variasi (bila ada), Grosir (bila ada), Ongkos Kirim dan Kondisi (Baru atau bekas) semenarik dan selengkap mungkin. Apabila telah selesai mengisi keterangan yang perlu diisi, maka klik "SIMPAN" dan produk otomatis diunggah ke laman toko akun penjual Shopee. Peserta juga diajarkan cara mengaktifkan saldo penjual, di mana uang hasil penjualan akan dikirimkan oleh Shopee ketika barang yang dikirim telah diterima oleh pembeli. Langkah-langkah memulai usaha melalui e-commerce Shopee ini juga dirangkum di dalam buku panduan yang dibuat oleh Tim KKN Tematik UNSRI dan diberikan kepada pihak desa dan kecamatan di akhir kegiatan KKN Tematik.

Materi yang disampaikan pada hari pertama dan kedua pelatihan sama, namun cara pelaksanaannya sedikit berbeda. Di mana pada hari pertama pendampingan peserta ketika menggunakan aplikasi Shopee dilakukan secara serentak dengan bantuan PowerPoint, sementara di hari kedua pendampingan dilakukan secara kelompok kecil agar lebih intens dan tidak perlu saling menunggu antar peserta. Dari dua hari pelatihan ini didapatkan 11 akun Shopee baru (5 di hari pertama dan 6 di hari kedua) yang mana di tiap akun Shopee tersebut telah diunggah satu produk unggulan desa berupa kerajinan Purun.

Selama dua hari pelatihan promosi digital ini, terdapat beberapa peserta yang antusias dan aktif bertanya selama pelatihan berlangsung. Para peserta yang antusias ini akan didampingi kembali setelah berakhirnya pelatihan di dalam program kerja utama Pendampingan UMKM dengan harapan para peserta tersebut berhasil melakukan proses penjualan online secara menyeluruh, dimulai dari pembuatan akun dan pengunggahan produk yang dilakukan selama pelatihan promosi digital ini, penerimaan pesanan dari pembeli, pengiriman produk kepada pembeli, hingga akhirnya peserta yang merupakan penjual tersebut berhasil menerima uang dari proses penjualan online ini.

\section{C.2 Pelatihan Videografi dan Fotografi Produk Unggulan Desa}

Konsep acara yang dibuat dalam kegiatan Pelatihan Videografi dan Fotografi Produk Unggulan Desa ini dibuat secara informal yang dimaksudkan agar para peserta lebih leluasa untuk langsung bertanya apabila ada hal yang ingin diketahui. Pelatihan ini dilaksanakan menyambung pelatihan promosi digital yang diadakan di awal, dengan demikian peserta dapat langsung menggunakan foto yang diambil di pelatihan ini untuk ditampilkan di etalase toko Shopee-nya.

Kegiatan ini diawali dengan penyampaian singkat tentang foto produk secara sederhana yang dapat dipahami oleh orang awam. Adapun penyampaian ini juga menunjukkan perbandingan antara foto produk yang kurang menarik dan juga foto produk yang lebih berkualitas dan menarik perhatian pembeli. Foto produk yang menarik sangat penting dalam pemasaran online karena pembeli mengandalakan foto tersebut sebagai acuan utama dalam pertimbangan untuk membeli produk. Apabila foto tersebut berkualitas rendah 
Jurnal SEMAR Vol. 10 No. 1, hal. $78-84$

ISSN: 2302-3937 | Copyright (C LPPM Universitas Sebelas Maret Homepage: https://jurnal.uns.ac.id/jurnal-semar

dan diambil seadanya, maka pembeli akan merasa kurang percaya dengan produk yang ditawarkan atau bahkan pembeli tidak tertarik untuk melihatnya sama sekali. Sementara jika foto produk berkualitas tinggi dan disusun sedemikain rupa hingga menarik untuk dilihat, maka pembeli akan merasa bahwa produk tersebut juga berkualitas dan mereka akan lebih percaya untuk membeli produk yang ditawarkan tersebut. Namun tentu foto produk yang dipasang di etalase online shop tidak boleh bersifat membohongi karena dapat berimbas kepada kepercayaan konsumen kedepannya. Melalui sesi ini, para peserta diberi pengetahuan akan pentingnya foto produk dalam pemasaran online sehingga mereka dapat terus memperhatikan pengambilan foto produk ketika ingin berjualan online nantinya.

Setelah menyampaikan materi singkat mengenai foto produk, para peserta langsung diajak untuk praktik langsung cara mengambil foto produk unggulan desa berupa kerajinan Purun dan juga kemplang. Untuk aktivitas ini diperlukan beberapa peralatan tambahan untuk menghasilkan foto produk yang lebih menarik. Adapun peralatan yang dimaksud adalah sepasang softbox (lampu pencahayaan) serta mini studio. Selain itu apabila diperlukan, tripod HP juga dapat digunakan untuk mendukung pengambilan foto produk.
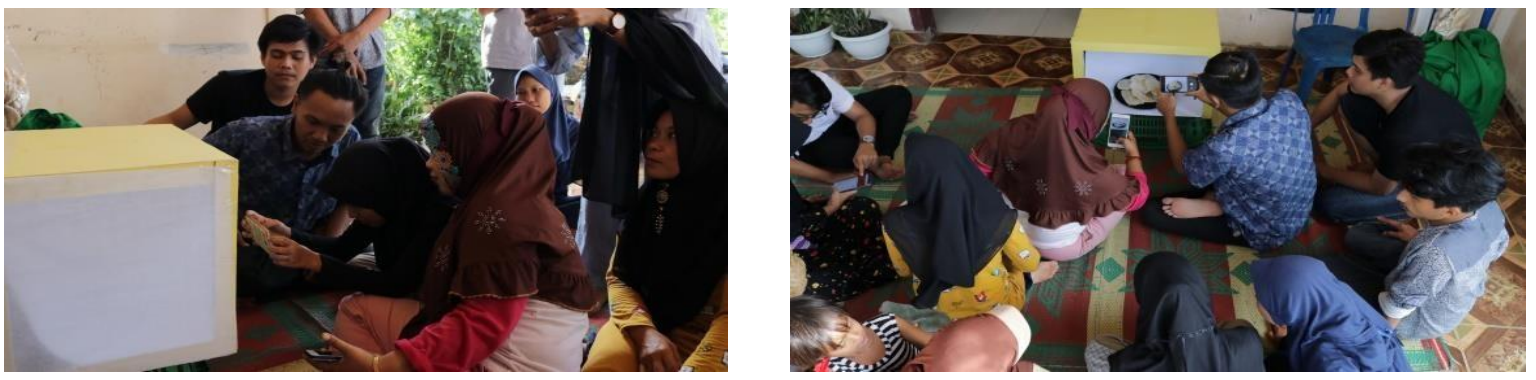

Gambar 3. Pendampingan peserta dalam pengambilan foto produk di hari pertama pelatihan fotografi

Mini studio yang digunakan dalam pelatihan ini merupakan mini studio yang dibuat sendiri oleh Tim KKN Tematik UNSRI dengan biaya yang minim. Adapun alat dan bahan yang dibutuhkan hanya karton padi tebal atau kardus, kertas minyak putih atau kalkir, karton putih, double tape atau lem, dan cutter atau gunting. Cara membuatnya juga cukup sederhana, apabila menggunakan kardus sebagai bahan utamanya, cukup lubangi tengah sisi depan, kiri, dan kadus dengan menyisakan sedikit kardus sebagai pinggiran (frame) mini studio. Setelahnya tempelkan kertas kalkir atau kertas minyak putih pada sisi kiri dan kanan kardus yang sudah dilubangi. Terakhir tempelkan karton putih untuk latar belakang pada satu sisi bagian yang terbuka dan biarkan ada bagian yang menjuntai dan tidak terputus. Dengan langkah-langkah sederhana ini didapatlah mini studio hasil kreasi sendiri. Adapun langkah- langkah pembuatan mini studio ini dirangkum dalam buku panduan yang dibuat oleh Tim KKN Tematik UNSRI yang diberikan kepada pihak desa dan kecamatan di akhir kegiatan KKN Tematik.
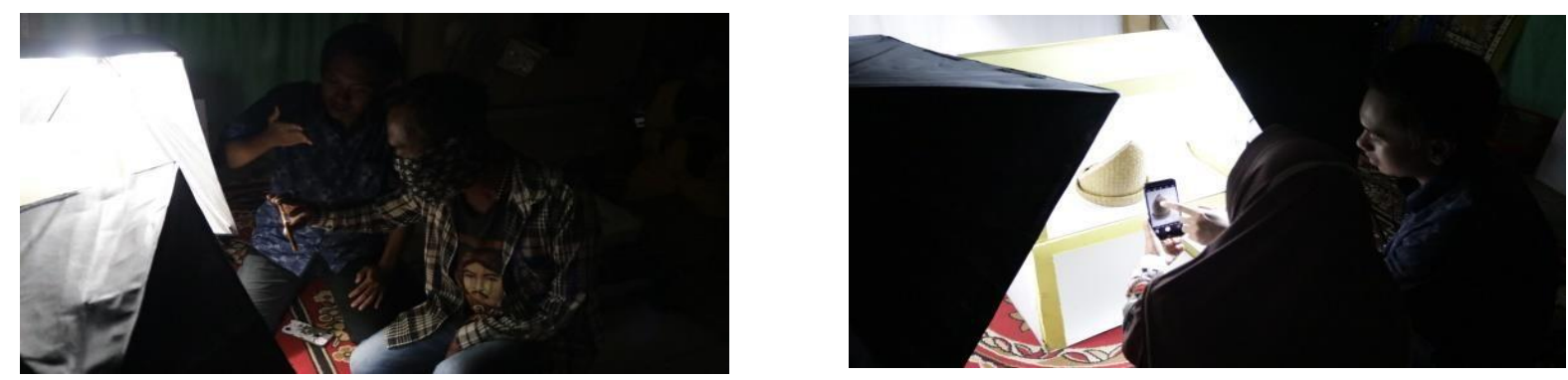

Gambar 4. Pendampingan peserta dalam pengambilan foto produk menggunakan softbox di hari kedua pelatihan fotografi 
Jurnal SEMAR Vol. 10 No. 1 , hal. $78-84$

ISSN: 2302-3937 | Copyright @ LPPM Universitas Sebelas Maret Homepage: https://jurnal.uns.ac.id/jurnal-semar

Softbox yang ada kemudian diletakkan di sisi kiri dan kanan mini studio (di bagian yang terdapat kertas kalkir atau kertas minyak) sebagai pencahayaannya. Apabila tidak memungkinkan untuk menggunakan softbox maka penggunaan lampu biasa yang diletakkan di samping mini studio juga dapat menghasilkan pencahayaan yang mendukung. Bahkan cahaya matahari alami di siang hari yang cerah juga dapat dijadikan sebagai medium pencahayaan. Namun penggunaan mini studio ini hanya diperuntukkan untuk barang-barang yang berukuran kecil, seperti kemplang, peci purun, tanjak purun, dompet atau tas kecil dari purun, dan kerajinan purun lainnya yang berukuran kecil. Untuk produk lain yang berukuran sedang hingga besar dapat menggunakan kain sebagai latar belakangnya dan didukung dengan pencahayaan menggunakan softbox. Adapun barang-barang dalam pelatihan fotografi berupa softbox, mini studio, tripod HP, serta kain backdrop akan ditinggalkan untuk Desa Menang Raya sehingga apabila terdapat masyarakat yang ingin mengambil foto produk yang menarik masih memiliki peralatan yang memadai.

Pengambilan foto produk yang dilakukan saat pelatihan berlangsung lebih terfokuskan dengan menggunakan mini studio, sehingga produk yang difoto merupakan produk yang berukuran kecil seperti kemplang, peci purun, tanjak purun, serta topi purun. Para peserta diajak untuk mencoba mengambil gambar satu per satu dan didampingi langsung oleh Tim KKN Tematik UNSRI dalam pengarahan teknik pengambilan gambar yang baik. Saat praktik pengambilan foto produk ini, para peserta aktif dalam bertanya dan mencoba mengambil gambar sehingga mereka dapat menerapkan pengetahuan dan tips yang diberikan dengan baik. Alhasil foto produk yang diambil di awal mula pelatihan (tanpa arahan) apabila dibandingkan dengan foto produk di akhir pelatihan memiliki kualitas yang lebih baik dan terlihat lebih menarik untuk dipajang di etalase online. Foto produk yang telah diambil ini juga langsung di-update di laman produk Shopee peserta yang dibuat di pelatihan promosi digital sebelumnya, sehingga para peserta telah memasarkan produknya secara online dengan menggunakan foto produk yang berkualitas dan menarik.

Para peserta yang antusias ini juga akan kembali didampingi pada program kerja utama Pendampingan UMKM apabila masih terdapat peserta yang ingin belajar lebih lanjut seputar pengambilan foto produk. Pengambilan foto ini juga tidak hanya dibatasi dengan produk unggulan desa seperti kerajinan purun dan kemplang saja, namun juga dengan produk-produk lain yang mungkin ingin dipasarkan oleh masyarakat Desa Menang Raya secara online. Tips \& trick pengambilan foto produk yang menarik dan professional ini juga turut dirangkum di dalam buku panduan yang disusun oleh Tim KKN Tematik UNSRI dan diberikan kepada pihak desa dan kecamatan di akhir kegiatan KKN Tematik.

\section{Kesimpulan}

Adapun kesimpulan yang dapat diambil dari kegiatan dengan judul "Pemberdayaan Wirausaha Melalui Digital Marketing Masyarakat Desa Menang Raya Kecamatan Pedamaran Kabupaten Ogan Komering Ilir" berhasil terlaksana dengan sangat baik, dilihat dari tercapainya tujuan kegiatan tiap program kerja yang ada, baik program kerja utama maupun program kerja pendampingan. Melalui program kerja utama, masyarakat Desa Menang Raya sadar akan besarnya andil pemasaran online (digital marketing) dalam memasarkan produk unggulan desa berupa kerajinan purun dan kemplang. Kesadaran ini didukung dengan pelatihan pembuatan akun $e$-commerce dan juga pengambilan foto produk agar menarik perhatian pembeli, sehingga masyarakat khususnya pengrajin purun dan pembuat kemplang siap untuk merintis bisnis online-nya. Pelatihan yang diikuti dengan pendampingan UMKM membuat masyarakat mendapat asistensi ketika mengeksplor bisnis online dan menjual produknya hingga akhirnya mereka mendapat pembeli pertama. Program kerja pendamping juga mendapat respon positif dari masyarakat, di mana masyarakat menerima hingga menghadiri program kerja pendamping yang diadakan. 
Jurnal SEMAR Vol. 10 No. 1, hal. $78-84$ ISSN: 2302-3937 | Copyright (C LPPM Universitas Sebelas Maret Homepage: https://jurnal.uns.ac.id/jurnal-semar

\section{Daftar Pustaka}

Kannan, P. K., \& Hongshuang, L. (2016). Digital Marketing: A Framework, Review and Research Agenda.

Purwana, Dedi dkk. 2017. Pemanfaatan digital marketing Bagi usaha mikro, kecil, dan menengah (umkm) di kelurahan malaka sari, duren sawit. Jurnal Pemberdayaan Masyarakat Madani (JPMM) Vol.1 No.1 2017 (Hal 1-17)

Utomo, R. M. (2016). http://m.metrotvnews.com/teknologi/news- teknologi/. Retrieved september 27, 2020, from metrotvnews.com: http://m.metrotvnews.com/teknologi/newsteknologi/GNGyEMrk- pemanfaatan-digital-marketing-di- indonesia-masih-minim

Wardhana, A. (2015). Strategi Digital Marketing dan Implikasinya pada Keunggulan Bersaing UKM di Indonesia 